\title{
Barotolerance of fungi isolated from deep-sea sediments of the Indian Ocean
}

\author{
Chandralata Raghukumar*, S. Raghukumar
}

National Institute of Oceanography, Dona Paula, Goa 403 004, India

\begin{abstract}
Two species of filamentous fungi, Aspergillus ustus (Bain.) Thom \& Church and Graphium sp., were isolated from calcareous animal shells at depths of $860 \mathrm{~m}$ in the Arabian Sea and $965 \mathrm{~m}$ in the Bay of Bengal. Laboratory experiments showed germination of conidia, growth of hyphae and microconidiation in both the fungi at 100 bar pressure at 10 and $30^{\circ} \mathrm{C}$, suggesting barotolerance. The fungi also secreted barotolerant protease under these conditions. Protease synthesised and secreted in cultures grown at 1 bar was also active under 100 bar pressure at 10 and $30^{\circ} \mathrm{C}$. At $10^{\circ} \mathrm{C}$, the fungi showed better conidial germination, growth and protease secretion when subjected to 100 bar than when grown at 1 atmosphere. The results indicate barotolerance of terrestrial species of fungi and suggest that they might be active under deep-sea conditions.
\end{abstract}

KEY WORDS: Barotolerance - Deep sea F Fungi $\cdot$ Enzymes $\cdot$ Protease

\section{INTRODUCTION}

Investigations on the occurrence and role of fungi in deep-sea sediments have received very little attention. Borings of calcareous animal shells in the deep sea, putatively by fungi, have been reported, but the fungi involved in this process have not been cultured (Rooney \& Perkins 1972, Zeff \& Perkins 1979). Two types of fungi, the obligate and facultative marine fungi, occur in the marine environment (Kohlmeyer \& Kohlmeyer 1979). The former grow and complete their life cycle only in the sea, whereas the 'facultative' ones are terrestrial or freshwater aquatic fungi which may also grow and reproduce in the marine environment. Five species of apparently indigenous deep-sea fungi in association with woody material have been reported (Kohlmeyer 1969). Terrestrial species of fungi (geofungi) have been isolated from the water column and sea floor at depths exceeding $500 \mathrm{~m}$ (Meyers \& Reynolds 1960, Roth et al. 1964, Hoehnk 1969, Poulicek 1983). Do such fungi qualify as 'facultative marine fungi' by growing and multiplying in this environment, or do they merely exist as dormant spores that have been carried from land? One way of addressing this

\footnotetext{
•E-mail: lata@csnio.ren.nic.in
}

problem is to examine the barotolerance of such fungi under laboratory conditions. Earlier, we demonstrated spore germination and calcium carbonate dissolution by a shell-boring geofungus under simulated deep-sea conditions (Raghukumar et al. 1992). Lorenz \& Molitoris (1992) reported barotolerance in several yeasts. We further report here growth of 2 such fungi isolated from the deep sea and synthesis and activity of their proteases under elevated hydrostatic pressure and low temperature.

\section{MATERIALS AND METHODS}

Isolation of fungi. Deep-sea sediments from the Bay of Bengal $\left(19^{\circ} \mathrm{N}, 86^{\circ} 06^{\prime} \mathrm{E}, 860 \mathrm{~m}\right.$ depth) and the Arabian Sea $\left(11^{\circ} \mathrm{N}, 72^{\circ} \mathrm{E}, 965 \mathrm{~m}\right)$ were collected during cruises \#4 of DSV 'Nand Rachit' and \#126 of FORV 'Sagar Sampada', respectively, using a Van Veen grab. Fungal isolations were carried out immediately in the laboratory on board. Partially degraded calcareous animal shells of about $10 \mathrm{~mm}$ size were sorted out from the sediments by sieving. The shell pieces were washed thoroughly with a jet of sea water and surface sterilised using $0.5 \%$ sodium hypochlorite solution for 3 min followed by 3 rinses with sterilised sea water 
(Newell \& Fell 1982). The shell pieces were incubated in a liquid medium containing $1 \%$ yeast extract, $1 \%$ peptone, $50 \mathrm{mg}$ streptomycin and 10000 units of penicillin $G$ in sea water ( 2 or 3 pieces $/ 5 \mathrm{ml}$ broth/tube). Antibiotics were incorporated in the isolation medium to inhibit bacterial. growth. Parallel to this, surface sterilised shell pieces were homogenised in a sterile pestle and mortar covered with a sterile plastic bag. Aliquots of $0.1 \mathrm{ml}$ sample were plated on cornmeal agar medium. Five replicates were maintained for each isolation. The whole operation was carried out in an inoculation chamber on board ship. Aerial contamination was checked by exposing Petri dishes with various media for 3 min in the working area and in the air over the open waters. A part of the sample was preserved in $3 \%$ formalin solution in sea water and stored at $5^{\circ} \mathrm{C}$ in a refrigerator for direct detection of fungal hyphae

After 15 to $20 \mathrm{~d}$ of incubation, shell pieces showing fungal growth were transferred to malt extract agar medium (MEA), Czapek-Dox agar (CDA) or potato dextrose agar (PDA) plates and the fungi were identified using standard taxonomic keys. The cultures were maintained on CDA or PDA slants. Aspergillus ustus (Bain.) Thom \& Church and Graphium sp. were the most commonly isolated fungi from the Bay of Bengal and the Arabian Sea respectively and were used in the present study.

Growth under elevated hydrostatic pressures. Effects of hydrostatic pressure and low temperature on (1) germination of conidia, (2) growth of germinated conidia, and (3) mycelial growth of the 2 test fungi were examined. The starter inoculum material for these tests was obtained by the following methods respectively.

(1) Conidial suspensions of the fungi were obtained by flooding the fungal colony growing on solid media (either CDA or PDA) with sterile sea water and decanted into a sterile flask containing sterile glass beads. The flasks were shaken on a wrist action shaker for $30 \mathrm{~min}$ to obtain a homogeneous suspension of conidia. (2) Conidia were germinated for $8 \mathrm{~h}$ in $1 \%$ glucose solution at 1 bar pressure, centrifuged and collected in sterile sea water. (3) Fungal cultures growing in liquid medium (CD broth) were used for preparing mycelial suspensions. After decanting the culture fluid from 3 d old cultures, the mycelia were homogenised with sterilised glass beads in sterile sea water.

Using glass spreaders, $0.1 \mathrm{ml}$ aliquots of (1), (2) and (3) were spread on a thin layer of (2 to $3 \mathrm{~mm}$ ) sea water agar medium containing $1.5 \%$ agar in plain sea water, without additional nutrients. Discs of $5 \mathrm{~mm}$ diameter were cut from these agar plates, introduced into polypropylene syringes of $2 \mathrm{ml}$ capacity and these were filled with sterile sea water up to the brim. The syringes used for culturing were modified by sawing off the nozzles. This resulted in open ended cylinders. These were sterilised before use. These syringes were closed with sterile rubber septa at one end and after introducing the culture medium or sea water and the fungal inoculum, the other end was also closed with a septum. Care was taken to avoid trapping of air bubbles while closing the septa. The septa were further covered with parafilm for additional safety.

Germination of spores on calcareous shells in the absence of additional nutrients was examined by dipping pieces of sterilised windowpane oyster shells in a conidial suspension for $15 \mathrm{~min}$. They were then transferred to sterile syringes filled with sterile sea water and subjected to pressure as described below.

The syringes with the inoculum discs/shell pieces were suspended in deep-sea culture vessels (Tsurumi \& Seiki Co., Japan) filled with sterile distilled water. These were pressurised to the desired hydrostatic pressures and incubated at 30 and $10^{\circ} \mathrm{C}$. Three replicate syringes, each with 5 discs/shell pieces with inoculum, were maintained for each of the experiments.

After $7 \mathrm{~d}$ of incubation, the deep-sea culture vessels were decompressed gradually (at the rate of ca $50 \mathrm{bar} /$ $5 \mathrm{~min})$, and the discs with inocula were immersed immediately in lactophenol-cotton blue stain and used for germination counts, measurements of mycelial lengths and photomicrography. Germination counts were made from 25 to 30 microscopic fields, each containing ca 20 to 30 conidia or mycelial pieces.

Estimation of fungal biomass under elevated hydrostatic pressure. Syringes containing liquid medium (CD broth prepared with $1 \%$ glucose) were inoculated with $0.1 \mathrm{ml}$ of mycelial suspension of test fungi, closed with rubber septa at both ends and suspended in pressure vessels. These were set to desired pressures and incubated. After $7 \mathrm{~d}$, triplicate cultures were vacuum filtered through tarred, preweighed Whatman GF/C filter papers, rinsed with $50 \mathrm{ml}$ of distilled water, dried to a constant weight and the cell mass was calculated by difference in weight of the initial inoculum and the final biomass.

Direct detection of fungal hyphae in shells. Direct detection of fungal hyphae within the formalinpreserved calcium carbonate shells was carried out immediately at the end of the cruise ( $30 \mathrm{~d}$ ) using the following methods. (1) Small shell pieces (ca $3 \mathrm{~mm}$ diameter) were put into acid-washed clean centrifuge tubes and filter sterilised solution of $5 \%$ EDTA was added. After dissolution of the shells, the contents of the tube were filtered over a $0.8 \mu \mathrm{m}$ black polycarbonate nucleopore filter, rinsed with filter sterilised sea water and stained with $0.01 \%$ Calcofluor solution (Sigma. Chemicals, St. Louis, MO, USA). The tilters were examined under an Olympus BHF epifluorescence microscope using blue-light excitation to detect fungal hyphae (Mueller \& Sengbusch 1983). 
(2) Shell pieces were mounted in a drop of $0.3 \mathrm{~N} \mathrm{HCl}$ containing Trypan blue stain and the slides were left overnight in moist chambers (Petri plates lined with moistened filter paper). After placing a cover glass on each slide, the partially decalcified shells were examined under a light microscope to detect fungal hyphae.

Effect of pressure on synthesis and activity of protease. Mycelial suspensions of test fungi were inoculated into $\mathrm{CD}$ broth with $1 \%$ casein as nitrogen source and $1 \%$ glucose as the carbon source at pH 7.0. After incubation for $7 \mathrm{~d}$ at desired hydrostatic pressures, the supernatants were collected after centrifugation at $10000 \mathrm{rpm}(7900 \times \mathrm{g})$ for $10 \mathrm{~min}$ at $4^{\circ} \mathrm{C}$. Protease activity in the supernatants was measured by the amount of tyrosine released from $1 \%$ casein substrate prepared in $0.1 \mathrm{M}$ phosphate buffer $(\mathrm{pH} 7.0)$ at $35^{\circ} \mathrm{C}$ by the following procedure. After incubating equal volumes of substrate and supernatant culture filtrate for $60 \mathrm{~min}$, an equal volume of $5 \%$ trichloroacetic acid (TCA) was added to the reaction mixture. After further incubation for $1 \mathrm{~h}$, the mixture was centrifuged and the amount of tyrosine in the clear supernatant was measured using Folin phenol reagent (Takami et al, 1990). One unit of activity was defined as the release of $1 \mu$ mol tyrosine from casein $\mathrm{min}^{-1}$. Activity was calculated as the difference between initial and final amounts of tyrosine released in the reaction mixture.

Effect of elevated hydrostatic pressure on protease activity was determined using Eppendorf tubes. The lids of the tubes were snapped off and sealed with parafilm after adding the reaction mixture. Care was taken to avoid trapping of air bubbles while sealing. The tubes were suspended in deep-sea culture vessels pressurised to the desired pressure and incubated at 30 and $10^{\circ} \mathrm{C}$ for $60 \mathrm{~min}$. At the end of the incubation period, the vessels were depressurised and without any delay the enzyme activity was arrested by adding TCA. Protease activity was measured as described above

\section{RESULTS}

Calcareous shells sorted out from deep-sea sediment samples appeared brown to black in color. After partial decalcification with EDTA, these shells appeared extensively bored with filamentous structures. Some of the shell pieces were also extremely transparent and infiltrated with borings by endolithic filamentous forms (Fig. 1). Sac-like structures with radiating branching tunnels were often found to be present in these shells (Figs. 2, 3 \& 4). On decalcification, filamentous structures were observed. Some of these shells showing such boring tunnels on decalcification revealed septate, branched filaments. Under an epifluorescence micro- scope, using a green excitation filter, they revealed no autofluorescence characteristic of photosynthetic organisms. Such filaments could also be clearly observed after staining with Trypan blue (Figs. 5 \& 6). Further, they fluoresced blue with calcofluor as is typical of fungi (Figs. $7 \& 8$ )

Nonsporulating mycelia were observed to grow out of shell pieces after 15 to $20 \mathrm{~d}$ of incubation in liquid medium. These sporulated when transferred onto agar plates. The most frequently isolated fungus from the Bay of Bengal was Aspergillus ustus (16 colonies out of a total of 40 colonies of fungi isolated) and that from the Arabian Sea was Graphium sp. (6 colonies out of a total of 10 colonies isolated).

Conidial germination of both the test fungi on plain sea water agar occurred at 100 and 200 bar hydrostatic pressures (Tables $1 \& 2$, Figs. $9-12$ ). At $10^{\circ} \mathrm{C}$, percentage germination was higher at 100 bar pressure than at 1 bar (Tables $1 \& 2$ ) in both the test fungi. The germ tubes and spores of Aspergillus ustus appeared unusually enlarged when grown under pressure at $30^{\circ} \mathrm{C}$ (Fig. 10). At $10^{\circ} \mathrm{C}$ such enlargement was not common. There were no such distinct morphological changes under pressure in Graphium sp. (Figs. 11 \& 12). The endolithic fungus observed on decalcifications of shell obtained from deep-sea sediment showed similar beaded structures (Figs. $7 \& 8$ ). Mycelial growth and further growth of germinated conidia also occurred under 100 bar pressure on plain sea water agar at both 10 and $30^{\circ} \mathrm{C}$ (Fig. 13). Both the test fungi showed microcyclic conidiation when grown under 100 bar pressure at $10^{\circ} \mathrm{C}$ but not at $30^{\circ} \mathrm{C}$ (Fig. 14). The Hülle cells of $A$. ustus germinated on shells under 100 bar pressure (Fig. 15). These cells were never observed to germinate at 1 bar pressure. Conidia of both the fungi germinated on shells in the absence of any additional nutrients at 10 and $30^{\circ} \mathrm{C}$ at 100 bar pressure (Fig. 16). Conidial germination was observed in plain sea water and in $1 / 5$ dilute malt extract broth also.

At $30^{\circ} \mathrm{C}$ the biomass of both the fungi in $1 \%$ glucose medium at 100 bar was much lower than that at 1 bar pressure. However, at $10^{\circ} \mathrm{C}$, the difference in growth between 1 and 100 bar was negligible in Aspergillus ustus (Fig. 17, Table 3). Similarly, the difference in growth under 100 bar pressure at 10 and $30^{\circ} \mathrm{C}$ was not significant in $A$. ustus (Table 3 ). The $F$-value for the temperature dependent response of growth to pressure was highly significant in Graphium sp. (Table 3). In general, growth was much lower at higher hydrostatic pressures and lower temperatures in both the test fungi.

Synthesis of protease was evident at 100 bar pressure in both the test fungi at 30 as well as $10^{\circ} \mathrm{C}$ (Fig. 18). On the whole, protease secretion in both the fungi was low at 100 bar (Fig. 18). The differences 


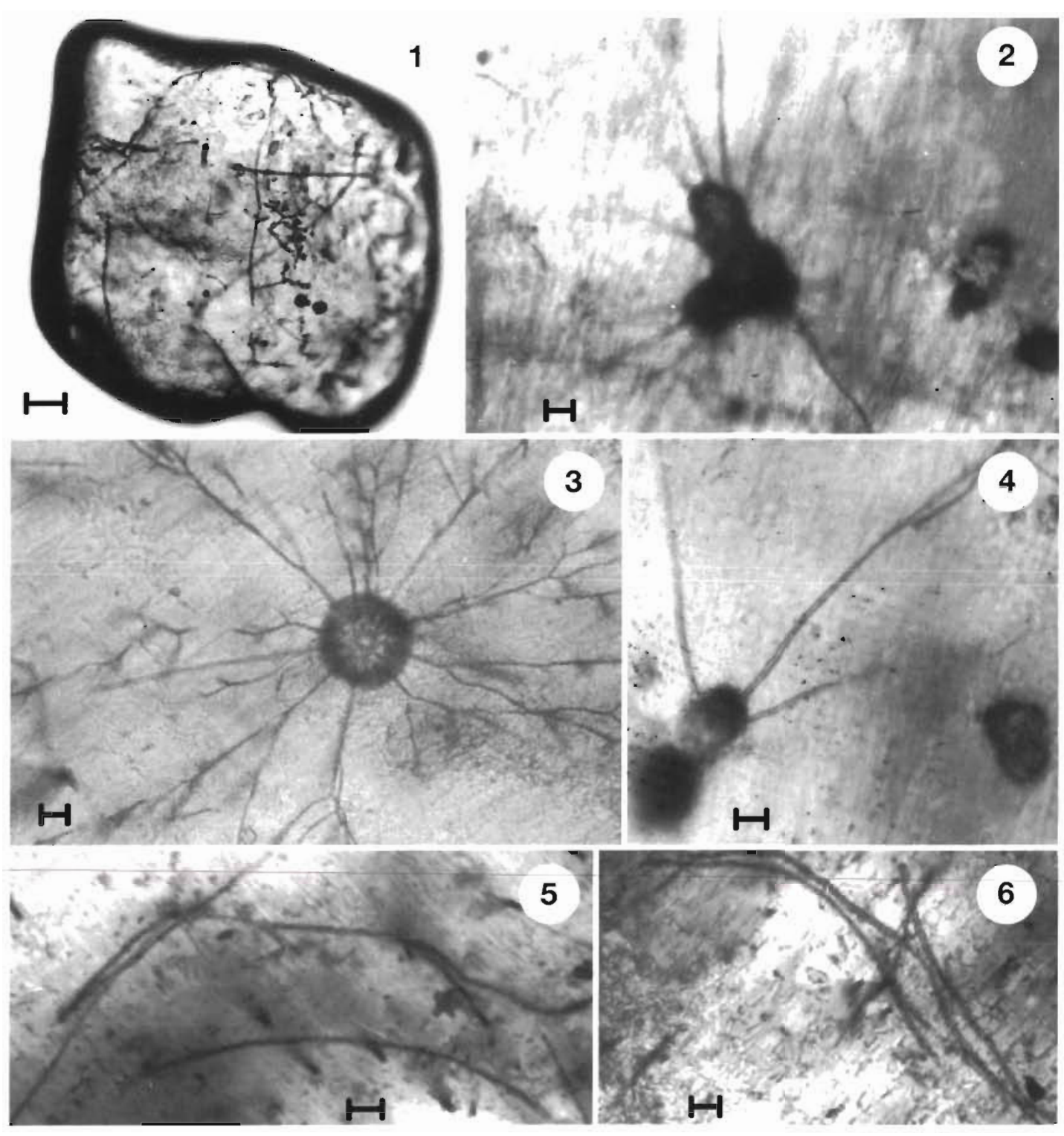

Fig. 1. Calcium carbonate shell from $860 \mathrm{~m}$ depth showing borings by endolithic filamentous forms. Scale bar $=100 \mu \mathrm{m}$. Figs. 2 to 4 . Sac-like cavities with radiating tunnels in shells recovered from $1000 \mathrm{~m}$ depth. Scale bars $=10 \mu \mathrm{m}$. Figs. $5 \& 6$. Fungal hyphae stained with Trypan blue visible after partial decalcification of shells. Scale bars $=10 \mu \mathrm{m}$

Table 1 Aspergillus ustus. Growth in $5 \mathrm{~d}$ at different hydrostatic pressures. +: growth present; ++: good growth; $+++:$ excellent growth

\begin{tabular}{|c|c|c|c|c|c|c|}
\hline & \multicolumn{2}{|c|}{1 bar } & \multicolumn{2}{|c|}{$100 \mathrm{bar}$} & \multicolumn{2}{|c|}{$200 \mathrm{bar}$} \\
\hline & $10^{\circ} \mathrm{C}$ & $30^{\circ} \mathrm{C}$ & $10^{\circ} \mathrm{C}$ & $30^{\circ} \mathrm{C}$ & $10^{\circ} \mathrm{C}$ & $30^{\circ} \mathrm{C}$ \\
\hline $\begin{array}{l}\% \text { spore } \\
\text { germination }\end{array}$ & $15.6 \pm 2.3$ & 100 & $\begin{array}{l}41.0 \pm 8.9 \\
\text { Normal germ tubes }\end{array}$ & $\begin{array}{l}78 \pm 10.4 \\
\text { Swollen germ tubes }\end{array}$ & $9.9 \pm 2.56$ & $64.8 \pm 9.98$ \\
\hline $\begin{array}{l}\text { Growth of } \\
\text { germinated } \\
\text { spores }(\mu \mathrm{m})\end{array}$ & 5.0 & +++ & $\begin{array}{c}7.5 \\
\text { Microconidiation } \\
\text { present }\end{array}$ & $21.5 \pm 6.2$ & Not done & Not done \\
\hline $\begin{array}{l}\text { Growth of } \\
\text { mycelium }(\mu \mathrm{m})\end{array}$ & 11.5 & +++ & $29.3 \pm 10.3$ & $84.8 \pm 18.9$ & Not done & Not done \\
\hline
\end{tabular}



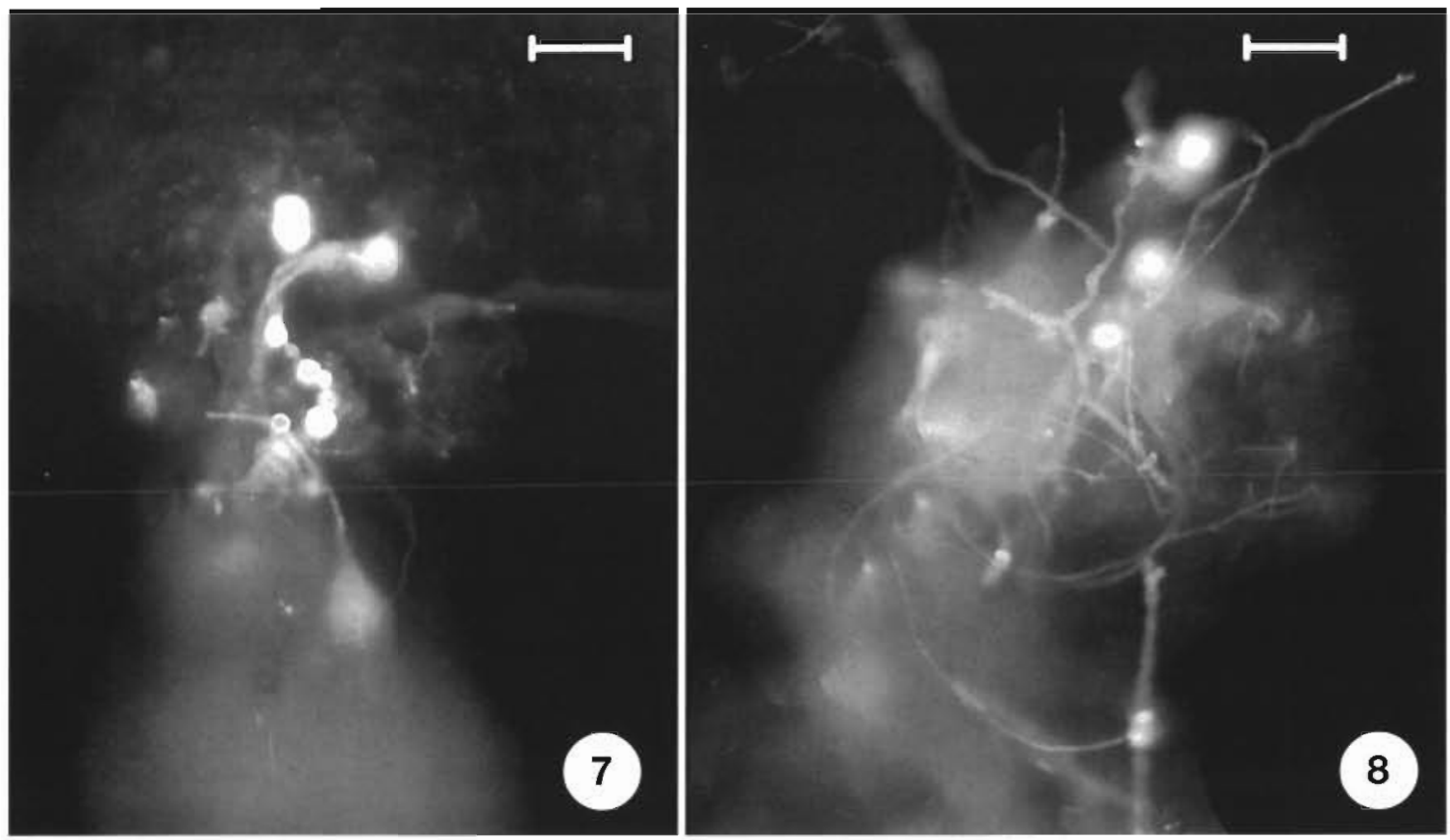

Figs. $7 \& 8$. Fungal hyphae visible after staining with calcofluor under epifluorescence microscope after dissolution of calcium carbonate shell with EDTA. Note the remnants of shell in the background. Scale bars $=10 \mu \mathrm{m}$

among various treatments were highly significant in both the fungi (Table 4). Although total activity was always much lower in cultures grown at $10^{\circ} \mathrm{C}$ (Fig. 18), when enzyme units were expressed per unit fungal biomass, in Aspergillus ustus the secretion of protease at $10^{\circ} \mathrm{C}$ was equal to that at $30^{\circ} \mathrm{C}$ under 1 bar or 100 bar pressure (Fig. 19). This fungus also secreted higher amount of protease per unit dry weight under 100 bar pressure than under 1 bar pressure (Fig. 19). In Graphium sp., lower temperature elicited higher secretion of protease per unit dry weight at both 1 and 100 bar pressures.

Protease synthesised in cultures grown at 1 bar/ $30^{\circ} \mathrm{C}$ showed much less activity at $10^{\circ} \mathrm{C}$. However, the same enzyme was much more active at $10^{\circ} \mathrm{C}$ when subjected to 100 bar pressure (Fig. 20). The 1-way ANOVA results revealed very highly significant differences among all the treatments in the 2 test fungi (Table 5).

\section{DISCUSSION}

Shell pieces with highly eroded margins and extremely fragile carbonate fragments similar to those observed by us have been reported earlier at depths up to $758 \mathrm{~m}$ from Carolina (USA) shelf sediments (Perkins \& Halsey 1971). Extensive fungal borings of calcium carbonate sediments have also been described from 210 to $1450 \mathrm{~m}$ in Bahamian waters (Zeff \& Perkins 1979). Destruction of deep-sea mussel shell by microorganisms having networking filaments broadly resembling chytrids and other fungi has been reported

Table 2. Graphium sp. Growth in $5 \mathrm{~d}$ at different hydrostatic pressures. +: growth present ; ++: good growth ; +++: excellent growth

\begin{tabular}{|c|c|c|c|c|c|c|}
\hline & \multicolumn{2}{|c|}{$1 \mathrm{bar}$} & \multicolumn{2}{|c|}{100 bar } & \multicolumn{2}{|c|}{$200 \mathrm{bar}$} \\
\hline & $10^{\circ} \mathrm{C}$ & $30^{\circ} \mathrm{C}$ & $10^{\circ} \mathrm{C}$ & $30^{\circ} \mathrm{C}$ & $10^{\circ} \mathrm{C}$ & $30^{\circ} \mathrm{C}$ \\
\hline $\begin{array}{l}\text { \% spore } \\
\text { germination }\end{array}$ & $12 . \overline{9} \pm 4.0$ & 100 & $\begin{array}{c}48.9 \pm 16.2 \\
\text { Normal germ tubes }\end{array}$ & $\begin{array}{l}89 \pm 4.1 \\
\text { Swollen germ tubes }\end{array}$ & $22.6 \pm 1.54$ & $37.7 \pm 4.53$ \\
\hline $\begin{array}{l}\text { Growth of } \\
\text { germinated } \\
\text { spores }(\mu \mathrm{m})\end{array}$ & + & +++ & $\begin{array}{c}\text { Microconidiation } \\
\text { present }\end{array}$ & $9.3 \pm 1.8$ & Not done & Not done \\
\hline $\begin{array}{l}\text { Growth of } \\
\text { mycelium }(\mu \mathrm{m})\end{array}$ & + & +++ & $30.9 \pm 11.0$ & $41.4 \pm 12.1$ & Not done & Not done \\
\hline
\end{tabular}



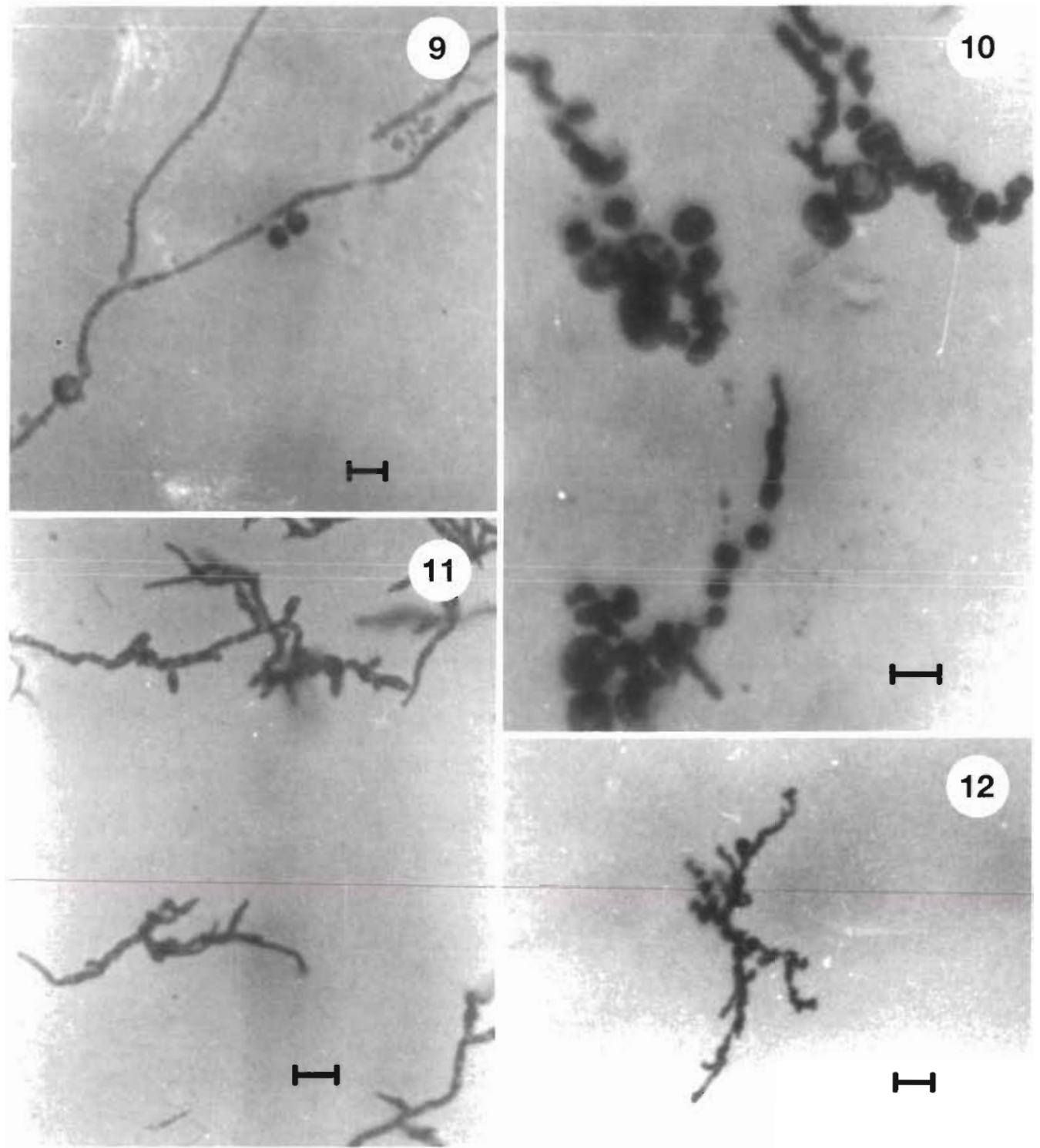

Fig. 9. Aspergillus ustus. Conidium germinated under 1 bar pressure. Scale bar $=10 \mu \mathrm{m}$. Fig. 10. Aspergillus ustus. Conldia germinated under 100 bar pressure. Scale bar $=10 \mu \mathrm{m}$. Fig. 11 Graphium sp. Conidia germinated under 100 bar pressure. Scale bar $=10 \mu \mathrm{m}$. Fig. 12. Graphium sp. Conidia germinated under 1 bar pressure. Scale bar $=10 \mu \mathrm{m}$

Table 3. One-way ANOVA (F-values) comparing the growth at various pressures/temperatures. df: degrees of freedom; ns: not significant; ${ }^{\prime} \cdot$ significant at $0.1 \% ;{ }^{\prime} \cdot$ significant at $1 \% ;$ 'significant at $2.5 \%$

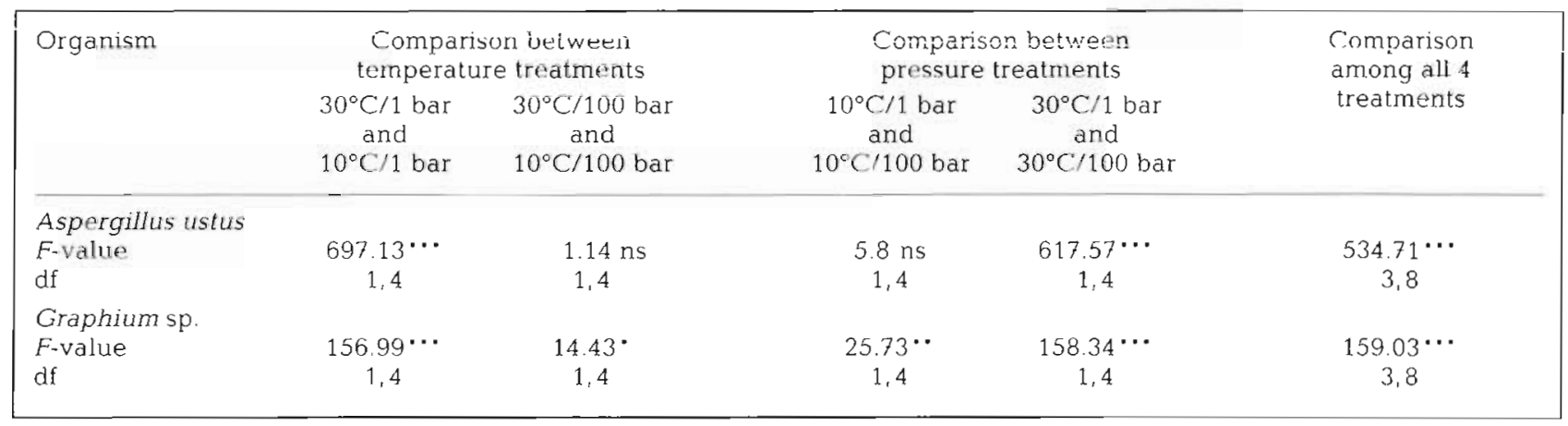




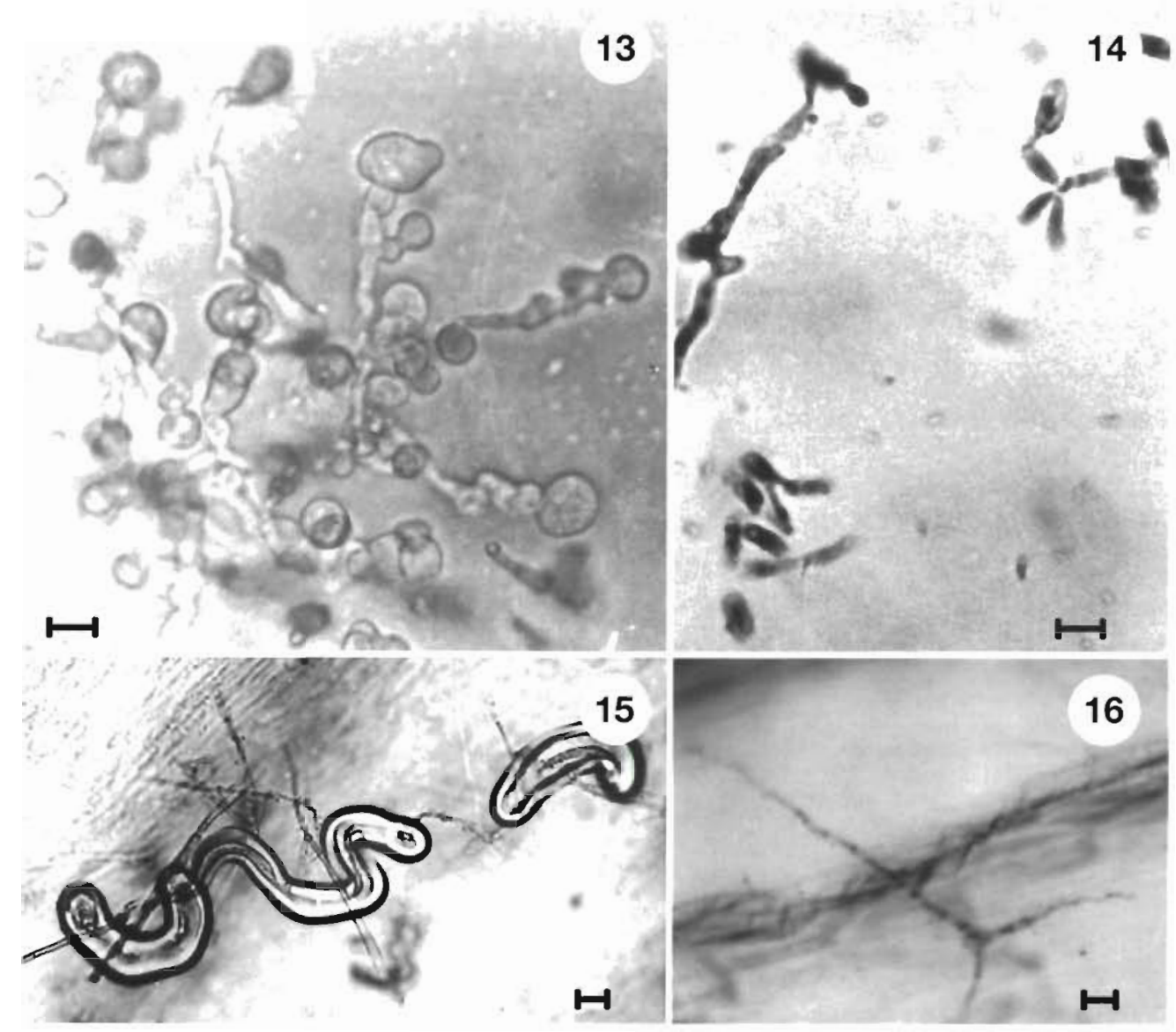

Fig. 13. Aspergillus ustus. Growth of mycelial hyphae under 100 bar pressure. Note the swollen tips of hyphae. Scalc bar $=10 \mu \mathrm{m}$. Fig. 14. Graphium sp. Microconidiation, where a conidium gives rise to conidia directly without intervening plıdse of hyphal growth. Scale bar $=5 \mu \mathrm{m}$. Fig. 15. Aspergillus ustus. Germination of Hülle cells at 100 bar pressure. Scale bar $=5 \mu \mathrm{m}$. Fig. 16. Germination of conidia under 100 bar pressure on shells suspended in sterile sea water. Scale har $=10 \mu \mathrm{m}$

by Hook \& Golubic (1993). Sac-like cavities with centrally radiating filaments as observed in our samples have been reported in deep-sea mussel shells (Hook \& Golubic 1993). Zeff \& Perkins (1979) have illustrated the presence of various morphologically different endolithic fungi in deep-sea carbonate fragments. These endolithic fungi are geologically important as producers of carbonate detritus in the deep sea (Tudhope \& Risk 1985). However, these boring endolithic fungi have not been cultured or identified.

Table 4. One-way ANOVA (F-values) comparing the effect of pressure and temperature on synthesis of protease. df: degrees of freedom; ns: not significant; ${ }^{\cdots} \cdot$ significant at $0.1 \% ; \cdot$ significant at $1 \% ; \cdot$ significant at $2.5 \%$

\begin{tabular}{|c|c|c|c|c|c|}
\hline \multirow[t]{2}{*}{ Organism } & \multicolumn{2}{|c|}{$\begin{array}{l}\text { Comparison between } \\
\text { temperature treatments }\end{array}$} & \multicolumn{2}{|c|}{$\begin{array}{l}\text { Comparison between } \\
\text { pressure treatments }\end{array}$} & \multirow{2}{*}{$\begin{array}{l}\text { Comparison } \\
\text { among all } 4 \\
\text { treatments }\end{array}$} \\
\hline & $\begin{array}{c}30^{\circ} \mathrm{C} / 1 \text { bar } \\
\text { and } \\
10^{\circ} \mathrm{C} / 1 \text { bar }\end{array}$ & $\begin{array}{c}30^{\circ} \mathrm{C} / 100 \text { bar } \\
\text { and } \\
10^{\circ} \mathrm{C} / 100 \mathrm{bar}\end{array}$ & $\begin{array}{c}10^{\circ} \mathrm{C} / 1 \text { bar } \\
\text { and } \\
10^{\circ} \mathrm{C} / 100 \text { bar }\end{array}$ & $\begin{array}{c}30^{\circ} \mathrm{C} / 1 \text { bar } \\
\text { and } \\
30^{\circ} \mathrm{C} / 100 \text { bar }\end{array}$ & \\
\hline $\begin{array}{l}\text { Aspergillus ustus } \\
\text { F-value } \\
\text { df }\end{array}$ & $\begin{array}{c}216.99 \cdots \\
1,4\end{array}$ & $\begin{array}{c}68.82 \cdots \\
1,4\end{array}$ & $\begin{array}{c}14.57^{\circ} \\
1.4\end{array}$ & $\begin{array}{c}128.17 \cdots \\
1,4\end{array}$ & $\begin{array}{c}157.23 \cdots \\
3,8\end{array}$ \\
\hline $\begin{array}{l}\text { Graphium sp. } \\
\text { F-value } \\
\text { df }\end{array}$ & $\begin{array}{c}44.78^{\cdots} \\
1.4\end{array}$ & $\begin{array}{l}0.91 \mathrm{~ns} \\
1,4\end{array}$ & $\begin{array}{c}19.75^{\circ} \\
1,4^{\circ}\end{array}$ & $\begin{array}{c}63.16^{\cdots} \\
1,4\end{array}$ & $\begin{array}{c}53.80^{\cdots} \\
3,8\end{array}$ \\
\hline
\end{tabular}




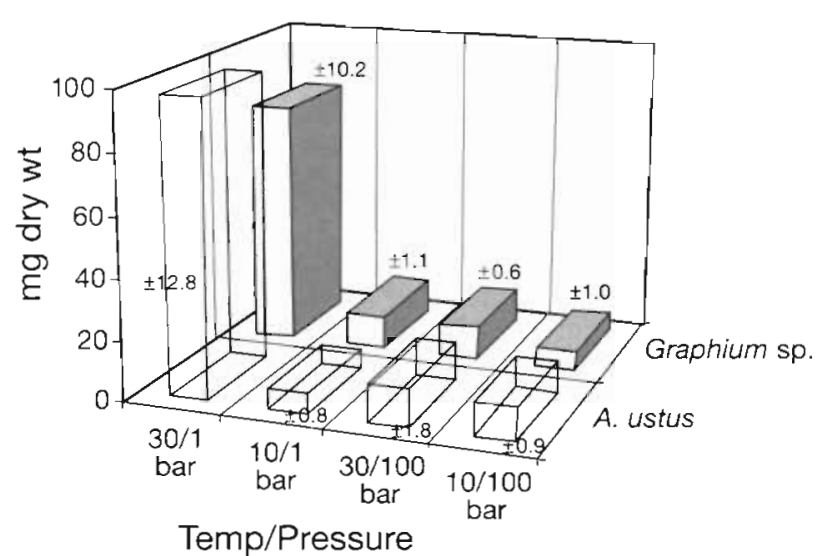

Fig. 17. Growth of test fungi (measured as mycelial dry wt in 7 d) under various temperature/pressure combinations. Values on bars represent standard deviation. Values are mean of 3 replicates at the $5 \%$ confidence level

The area sampled by us, namely the continental shelf of the Arabian Sea around the Lakshadweep Islands and the Bay of Bengal, is known to be inhabited by bivalves (Ingole et al. 1972, Ansari et al. 1977). In the Bay of Bengal at a depth of $1000 \mathrm{~m},>1000 \mathrm{~mol}-$ luscs $\mathrm{m}^{-2}$ have been reported (Ansari et al. 1977). Therefore, the calcareous shells examined by us appear to be autochthonous. However, the shell pieces were very fragile and too minute to be identified.

Deep-sea conditions appear to induce morphological changes in germinating conidia and mycelia. Both Aspergillus ustus and Graphium sp. displayed similar morphological changes when grown under pressure (Figs. 9-14). Swollen hyphae and conidia with thicker walls as observed by us have also been reported in a deep-sea yeast isolate and A. niger by Lorenz (1993). Spherical cells might be an adaptation by these fungi

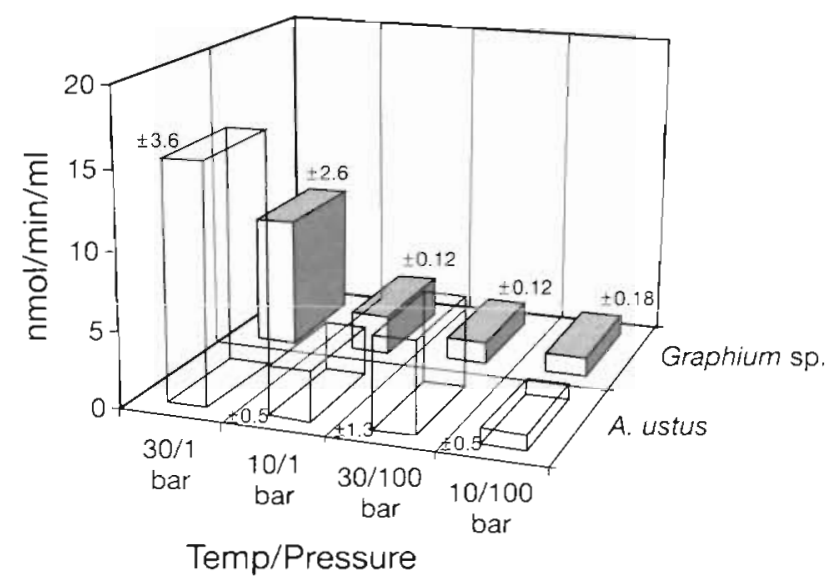

Fig. 1.8. Protease synthesis in the 2 test fungi under various temperature/pressure combinations. Values on bars represent standard deviation. Values are mean of 3 replicates at the $5 \%$ confidence level

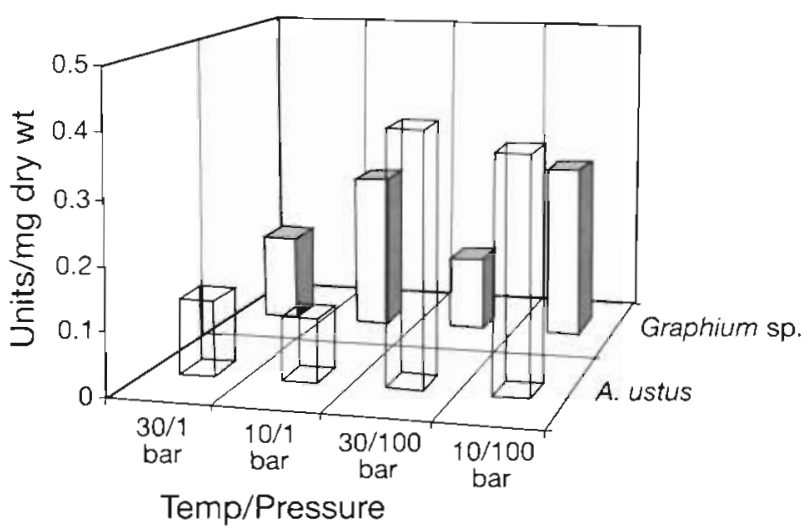

Fig. 19. Protease synthesis in the 2 test fungi expressed as units/unit fungal biomass. Values are derived from Figs. $17 \& 18$

for pressure tolerance. Beaded hyphal structures, as observed in natural samples (Figs. $7 \& 8$ ), were also observed under simulated laboratory conditions (Figs. 10, $11 \&$ 13). The process of microconidiation in species of Aspergillus is common when they are grown under stress (Saxena et al. 1992). In microcyclic conidiation, immediate conidiation occurs following conidial germination without an intervening phase of prolonged vegetative mycelium. Microconidiation is reported to occur under nutrient-limiting conditions (see Saxena et al. 1992) and might help the fungi to complete their life cycles in a shorter time. Germination of conidia and growth of mycelium in the 2 species of terrestrial fungi under hydrostatic pressures of 100 and 200 bar, albeit lower than that at $1 \mathrm{bar}$, indicate their capability to withstand deep-sea high pressure conditions. Germination of spores of both the test fungi on discs of plain agar in sea water medium and on shell pieces suspended in sea water

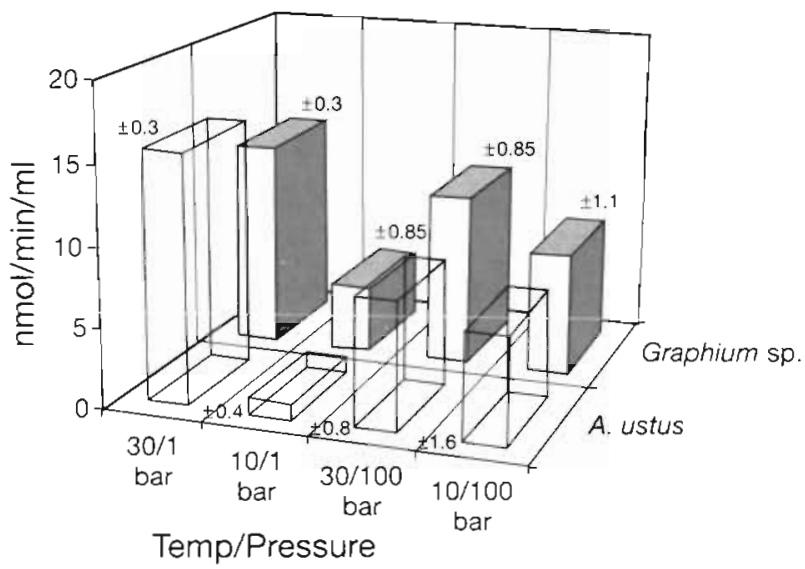

Fig. 20. Culture filtrates from fungi grown at $30^{\circ} \mathrm{C} / 1$ bar tested for protease activity under various temperature/pressure combinations. Values are mean of 3 replicates at the $5 \%$ confidence level 
Table 5. One-way ANOVA ( $F$-values) comparing the effect of pressure and temperature on the activity of protease. df: degrees of freedom; ns: not significant; $\cdots$ significant at $0.1 \%$; " significant at $1 \%$; 'significant at $2.5 \%$

\begin{tabular}{|c|c|c|c|c|c|}
\hline \multirow[t]{2}{*}{ Organism } & \multicolumn{2}{|c|}{$\begin{array}{l}\text { Comparison between } \\
\text { temperature treatments }\end{array}$} & \multicolumn{2}{|c|}{$\begin{array}{l}\text { Comparison between } \\
\text { pressure treatments }\end{array}$} & \multirow{2}{*}{$\begin{array}{l}\text { Comparison } \\
\text { among all } 4 \\
\text { treatments }\end{array}$} \\
\hline & $\begin{array}{l}30^{\circ} \mathrm{C} / 1 \text { bar } \\
\text { and } \\
10^{\circ} \mathrm{C} / 1 \text { bar }\end{array}$ & $\begin{array}{c}30^{\circ} \mathrm{C} / 100 \text { bar } \\
\text { and } \\
10^{\circ} \mathrm{C} / 100 \text { bar }\end{array}$ & $\begin{array}{c}10^{\circ} \mathrm{C} / 1 \text { bar } \\
\text { and } \\
10^{\circ} \mathrm{C} / 100 \text { bar }\end{array}$ & $\begin{array}{c}30^{\circ} \mathrm{C} / 1 \text { bar } \\
\text { and } \\
30^{\circ} \mathrm{C} / 100 \text { bar }\end{array}$ & \\
\hline $\begin{array}{l}\text { Aspergillus ustus } \\
\text { F-value } \\
\text { df }\end{array}$ & $\begin{array}{c}2593.1 \cdots \\
1,4\end{array}$ & $\begin{array}{l}1.58 \mathrm{~ns} \\
1,4\end{array}$ & $\begin{array}{l}35.83^{*} \\
1.4\end{array}$ & $\begin{array}{l}243.66^{\cdots} \\
1,4\end{array}$ & $\begin{array}{c}127.41 \cdots \\
3.8\end{array}$ \\
\hline $\begin{array}{l}\text { Graphium sp. } \\
\text { F-value } \\
\text { df }\end{array}$ & $\begin{array}{l}287.81 \cdots \\
\quad 1,4\end{array}$ & $\begin{array}{c}14.59^{\circ} \\
1,4\end{array}$ & $\begin{array}{c}19.37^{\circ} \\
1,4^{\circ}\end{array}$ & $\begin{array}{c}18.39^{\circ} \\
1,4\end{array}$ & $\begin{array}{c}64.28 \cdots \\
3.8\end{array}$ \\
\hline
\end{tabular}

indicates adaptation of these 2 geofungi to deep-sea oligotrophic conditions. We have shown earlier that conidia of $A$. ustus (reported as $A$. restrictus earlier) germinated on plain calcium carbonate shells at 300 bar (Raghukumar et al. 1992).

Calcareous shells have an organic matrix of conchyolin, a horny protein which is known to be used by endolithic fungi as a nutrient source (Alderman 1976). In light of this, synthesis and activity of protease under pressure and at low temperature are of great significance to these endolithic deep-sea fungi for survival.

These fungi appear to tolerate lower temperature better when subjected to elevated hydrostatic pressure. This was evident from increased growth, germination of conidia and synthesis and activity of protease at $10^{\circ} \mathrm{C}$ under 100 bar pressure when compared to $10^{\circ} \mathrm{C}$ at 1 bar pressure (see Tables 1 \& 2, Figs. 17-20). However, on the whole, germination of conidia, growth and production of protease were higher under $30^{\circ} \mathrm{C} / 100$ bar than under $10^{\circ} \mathrm{C} / 100$ bar combinations in both the test fungi. Although the former is not a common natural environmental condition in the deep sea, it might be expected to occur in the vicinity of hydrothermal vents. The existence and role of endolithic fungi in deep-sea calcium carbonate shells at elevated temperatures would be worth investigating.

Reduced growth and low metabolic rates under deep-sea conditions are well reported in bacteria (Wirsen \& Jannasch 1975). In this context, reduced growth and low enzyme activity under pressure by the 2 test fungi is to be expected. However, reduced activity of protease from cultures grown at $30^{\circ} \mathrm{C} / 1 \mathrm{bar}$ under 100 bar pressure might be due to a change in affinity of enzyme to substrate supposed to be brought about by changes in tertiary or quaternary structure of enzymes under pressure (Landau \& Pope 1980). Reduction of malate dehydrogenase activity in response to elevated pressure in a marine bacterium grown under 1 bar pressure has been demonstrated
(Mohankumar \& Berger 1972). Extracellular chitinases of bacterial strains from the Antarctic Ocean showed high barotolerance (Helmke \& Weyland 1986). Further, these authors reported that low temperatures reduced the chitinase activity but not barotolerance. Such detailed studies are totally lacking for filamentous fungi.

Several culturable fungi such as Cladosporium spp., Alternaria spp., Aspergillus sydowi, Nigrospora spp., and Penicillium solitum from deep-sea water samples (below $500 \mathrm{~m}$ depth) have been reported from different geographical locations (Roth et al. 1964, Raghukumar et al. 1992). However, these are not obligate marine fungi, in the sense that they are not exclusive to the marine environment, and are common terrestrial species and, therefore, a controversy has persisted about their existence and role in the marine environment (Kohlmeyer \& Kohlmeyer 1979). Nevertheless, several instances of active involvement of geofungi in marine processes, particularly associated with calcium carbonate shells, have been reported in recent times. Kendrick et al. (1982) reported several terrestrial fungi associated with live corals and have suggested their role as possible bioeroders. The existence of fungi as opportunistic pathogens in corals under environmental stress has been suggested by Le Campion-Alsumard et al. (1995). A terrestrial fungus, Aspergillus fumigatus, was reported as the putative fungal pathogen of seafan, causing mass mortalities in the Caribbean (Smith et al. 1996). Similarly, we have reported yet another geofungus, Scolecobasidium sp., associated with necratic patches in massive corals in the Andaman Islands in the Bay of Bengal (Raghukumar \& Raghukumar 1991). Scolecobasidium sp. and Ochroconis humicola were also reported as fish pathogens (Ross \& Yasutake 1973, Schaumann \& Priebe 1994). A species of Acremonium was reported as a fungal pathogen of the marine filamentous green alga Cladophora sp. (Bott \& Rogenmuser 1980). The association and potential role of geofungi in coastal marine 
plant litter system are well known (Cundell et al. 1979, Fell \& Newell 1981, Cuomo et al. 1985, Raghukumar et a.l. 1994, Sharma et al. 1994). Our present study lends further credence to the view that terrestrial fungi do occur in the marine environment and play an active role under these conditions. Such fungi would correspond to 'facultative marine fungi', as defined by Kohlmeyer \& Kohlmeyer (1979).

Not all terrestrial or marine fungi are capable of barotolerance. Our earlier studies showed that spores of Aspergillus niger, a terrestrial fungus isolated from calcareous shells from sandy beaches, did not germinate under 100 and 200 bar pressure (Raghukumar et al. 1992). An isolate of A, niger tested by Lorenz (1993) showed extremely stunted growth at 200 bar. Kriss \& Zaichkin (in Lorenz 1993) showed that germination of spores of several terrestrial fungal isolates was completely inhibited at 300 bar. Two shallow-water marine fungi, Dendryphiella salina and Asteromyces cruciatus, showed no growth above 100 bar pressure (Lorenz 1993). The ability of some species to grow over a wide range of pressures will enhance their role in remineralisation process in the deep sea and influence geochemical cycles in the oceans (Turley \& Carstens 1991).

The areas sampled by us were about $300 \mathrm{~km}$ from the coast. Spores and hyphal fragments of terrestrial fungi may get deposited in deep-sea sediments in close proximity to the coast through terrestrial runoff, sedimentation, currents and air blown from the land. Saprobic fungi are known for their wide variety of physiological and genetic adaptations (Wainwright 1988) and it could be expected that at least some 'geofungi' have acquired barotolerance sufficient enough to play an active role in deep-sea sediments. Germination of spores, growth of mycelium and enzyme production under simulated deep-sea conditions by the 2 experimental fungi indicate their active involvement in marine habitats.

Turley (1993) showed a diminishment of activities of surface microbes attached to sinking particles with depth and concluded that only resident benthic microbes play a major role in deep-sea processes. Our results indicate that at least some terrestrial fungi could have acquired a 'resident status' in deep-sea sediments and could be involved in dissolution of calcium carbonate and remineralisation of organic matter. Further proof in the form of immunofluorescence or molecular probes for detection of such fungi in situ is required to confirm this.

Acknowledgements. We are grateful to Dr D. Chandramohan for his help and encouragement throughout this work. This is N.I.O.'s Contribution No. 2547.

\section{LITERATURE CITED}

Alderman DJ (1976) Fungal diseases of animals. In: Jones EBG (ed) Recent advances in aquatic mycology. Elek Science, London, p 223-260

Ansari ZA, Harkantra SN, Nair SA, Parulekar AH (1977) Benthos of the Bay of Bengal: a preliminary account. Mahasagar, Bull Natl Inst Oceanogr 10:55-60

Bott T.L, Rogenmuser K (1980) Fungal pathogen of Cladophora glomerata (Chlorophyta). Appl Environ Microbiol 40:977-980

Cundell AM, Brown MS, Stanford R, Mitchell R (1979) Microbial degradation of Rhizophora mangle leaves immersed in the sea. Estuar Coast Mar Sci 9:281-286

Cuomo VF, Vanzanella E, Fresi F, Cinelli K, Mazzella L (1.985) Fungal flora of Posidonia oceanica and its ecological significance. Trans Br Mycol. Soc 84:35-40

Fell JW, Newell SY (1981) Role of fungi in carbon flow and nitrogen immobilisation in coastal marine plant Iitter systems. In: Wicklow DT, Carroll GC (ed) The fungal community. Marcel Dekker Inc., New York, p 665-678

Helmke E, Weyland $H$ (1986) Effect of hydrostatic pressure and temperature on the activity and synthesis of chitinases of Antarctic ocean bacteria. Mar Biol 91:1-7

Höhnk W (1969) Über den pilzlichen Befall kalkiger Hartteile von Meerestieren. Ber Dtsch Wiss Komm Meeresforschung 20:129-140

Hook JE, Golubic S (1993) Microbial shell destruction in deep-sea mussels, Florida Escarpment. PSZN I: Mar Ecol 14:81-90

Ingole BS, Ansari ZA, Parulekar AH (1972) Benthic fauna around Mauritius island, Southwest Indian Ocean. Indian J Mar Sci 21:268-273

Kendrick B, Risk MJ. Michaelides J, Bergman K (1982) Amphibious microborers: bioeroding fungj isolated from live corals. Bull Mar Sci 32:862-867

Kohlmeyer J (1969) The role of marine fungi in the penetration of calcareous substances. Am Zool 9:741-746

Kohlmeyer J, Kohlmeyer E (1979) Marine mycology. The higher fungi. Academic Press, New York

Landau JV, Pope DH (1980) Recent advances in the area of barotolerant protein synthesis in bacteria and implications concerning barotolerant and barophilic growth. In: Droop MR, Jannasch HW (eds) Advances in aquatic microbiology. Academic Press, London, p 49-76

Le Campion-Alsumard T, Golubic S, Priess K (1995) Fungı in corals: symbiosis or disease? Interaction between polyps and fungi causes pearl-like skeleton biomeralisation. Mar Ecol Prog Ser 117:137-147

Lorenz R (1993) Kultivierung mariner Pilze unter erhöhtem hydrostatischen Druck. PhD thesis, University of Regensburg

Lorenz R, Molitoris HP (1992) High pressure cultivation of marine fungi: cultivation experiments. In: Balny $\mathrm{C}$, Hayashi R. Masson P (eds) High pressure and biotechnology. John Libbey \& Company, London, p 315-319

Meyers SP, Reynolds ES (1960) Occurrence of lignicolous fungi in Northern Atlantic and Pacific marine localities Can J Bot 38:217-226

Mohankumar KC, Berger LR (1972) A method for rapid enzyme kinetic assays at increased hydrostatic pressure. Analyt Biochem 49:336-342

Mueller V, Sengbusch PV (1983) Visualisation of aquatic fungi (Chytridiales) parasitising on algae by means of induced fluorescence. Arch Hydrobiol 97:471-485

Newell SY, Fell JW (1982) Surface sterilisation and the active mycoflora of leaves of a seagrass. Bot Mar 25:339-346 
Perkins RD, Halsey SD (1971) Geologic significance of microboring fungi and algae in Carolina shelf sediments. I Sediment Petrol 41:843-853

Poulicek M (1983) Patterns of mollusk shell biodegradation in bathyal and abyssal sediments. J Mollusk Stud Suppl 12A: $136-141$

Raghukumar C, Raghukumar S (1991) Fungal invasion of massive corals. PSZN 1: Mar Ecol 12:251-260

Raghukumar C, Raghukumar S, Sharma S, Chandramohan D (1992) Endolithic fungi from deep-sed calcareous substrata: isolation and laboratory studies. In: Deasai BN (ed) Oceanography of the Indian Ocean. Oxford IBH Publ, New Delhi, p 3-9

Raghukumar S, Sharma S, Raghukumar C, Sathe-Pathak V, Chandramohan D (1994) Thraustochytrid and fungal component of marine detritus. Il. Laboratory studies on decomposition of leaves of the mangrove Rhizophora apiculata Blume. J Exp Mar Biol Ecol 183:113-131

Rooney WS, Perkins RD (1972) Distribution and geologic significance of microboring organisms within sediments of the Arlington Reef Complex-Australia. Geol Soc Am Bull 83:1139-1150

Ross AJ, Yasutake WT (1973) Scolecobasidium humicola, a fungal pathogen of fish. J Fish Res Bd Can 32:1648-1652

Roth FJ, Orpurt PA, Ahearn DJ (1964) Occurrence and distribution of fungi in a subtropical marine environment. Can J Bot 42:375-383

Saxena RK, Khurana N, Kuhud RC, Gupta R (1992) D-glucose soluble starch, a novel medium for inducing microcyclic conidiation in Aspergillus. Mycol Res 96:490-494

Schaumann K. Priebe K (1994) Ochroconis humicola causing

Editorial responsibility: Karin Lochte,

Warnemünde, Germany muscular black spot disease of Atlantic salmon (Salmo salar L.). Can J Bot 72:1629-1634

Sharma S, Raghukumar C, Raghukumar S, Sathe-Pathak V, Chandramohan D (1994) Thraustochytrid and fungal component of marine detritus. II. Laboratory studies on decomposition of the brown alga Sargassum cinereum J.Ag. J Exp Mar Biol Ecol 175:227-242

Smith GW. Nagelkeiken IA, Ritchie KB (1996) Caribbean sea-fan mortalities. Nature 383:487

Takami H, Akiba T, Horikoshi K (1990) Characterisation of an alkaline protease from Bacillus sp. No. AH 101. Appl Microbiol Biotech 33:519-52.3

Tudhope AW, Risk MJ (1985) Rate of dissolution of calcium carbonate sediments by microboring organisms from Devon Reef Australia. J Sediment Petrol 55:440-447

Turley CM (1993) The effect of pressure on leucine and thymidine incorporation by free-living bacteria and by bacteria attached to sinking oceanic particles. Deep Sea Res 40:2193-2206

Turley CM, Carstens M (1991) Pressure tolerance of oceanic flagellates: implications for remineralisation of organic matter. Deep Sea Res 38:403-413

Wainwright $M$ (1988) Metabolic diversity of fungi in relation to growth and mineral cycling in soil-a review. Trans Br Mycol Soc 90:159-170

Wirsen CO, Jannasch HW (1975) Activity of marine psychrophilic bacteria at elevated hydrostatic pressures and low temperatures. Mar Biol 31:201-208

Zeff ML, Perkins RD (1979) Microbial alteration of Bahamian deep-sea carbonates. Sedimentology 26 : $175-201$

Submitted: June 25, 1997; Accepted: January 23, 1998 Proofs received from author(s): May 11, 1998 